\title{
Pragmatic applications of implementation science frameworks to regulatory science: an assessment of FDA Risk Evaluation and Mitigation Strategies (REMS) (2014-2018)
}

\author{
Linda Huynh ${ }^{1,2}$, Gita A. Toyserkani ${ }^{1 *}$ (D) and Elaine H. Morrato ${ }^{1,3,4}$
}

\begin{abstract}
Background: A Risk Evaluation and Mitigation Strategy (REMS) is a drug safety program for certain medications with serious safety concerns required by the U.S. Food and Drug Administration (FDA) of manufacturers to implement to help ensure the benefits of the medication outweigh its risks. FDA is encouraging "the research community to develop novel methods for assessing REMS," conveying the unmet need for a standardized evaluation method of these regulatory-mandated healthcare programs. The objective of this research is to evaluate FDA REMS assessment plans using established implementation science frameworks and identify opportunities for strengthening REMS evaluation.
\end{abstract}

Methods: A content analysis was conducted of publicly available assessment plans for all REMS programs $(N=23)$ approved 1/1/2014-12/31/2018 for new drug applications (NDAs) and biologics license applications (BLAs) requiring FDA-mandated Elements to Assure Safe Use (ETASU). Blinded reviewers critically appraised REMS assessment measures $(n=674)$ using three established implementation science frameworks: RE-AIM (Reach, Effectiveness, Adoption, Implementation, Maintenance); PRECEDE-PROCEED (Predisposing, Reinforcing, and Enabling Constructs in Educational/Environmental Diagnosis and Evaluation - Policy, Regulatory, and Organizational Constructs in Educational and Environmental Development); and CFIR (Consolidated Framework for Implementation Research). Framework constructs were mapped to REMS Assessment categories as defined by FDA Guidance for Industry to evaluate congruence.

Results: REMS assessment measures demonstrated strong congruence ( $>90 \%$ mapping rate) with the evaluative constructs of RE-AIM, PRECEDE-PROCEED, and CFIR. Application of the frameworks revealed that REMS assessment measures heavily emphasize implementation and operations, focus less on health outcomes, and do not evaluate program context and design assumptions.

Conclusions: Implementation science frameworks have utility for evaluating FDA-mandated drug safety programs including the selection of primary measures to determine whether REMS goals are being met and of secondary measures to evaluate contextual factors affecting REMS effectiveness in varying organizational settings.

Keywords: FDA, Drug safety, Risk Evaluation and Mitigation Strategies (REMS), Assessment, RE-AIM, PRECEDEPROCEED, CFIR, Implementation science

\footnotetext{
* Correspondence: gita.toyserkani@fda.hhs.gov

${ }^{1}$ Food and Drug Administration, Silver Spring, MD, USA

Full list of author information is available at the end of the article
}

C C The Author(s). 2021 Open Access This article is licensed under a Creative Commons Attribution 4.0 International License, which permits use, sharing, adaptation, distribution and reproduction in any medium or format, as long as you give appropriate credit to the original author(s) and the source, provide a link to the Creative Commons licence, and indicate if changes were made. The images or other third party material in this article are included in the article's Creative Commons licence, unless indicated otherwise in a credit line to the material. If material is not included in the article's Creative Commons licence and your intended use is not permitted by statutory regulation or exceeds the permitted use, you will need to obtain permission directly from the copyright holder. To view a copy of this licence, visit http://creativecommons.org/licenses/by/4.0/ The Creative Commons Public Domain Dedication waiver (http://creativecommons.org/publicdomain/zero/1.0/) applies to the data made available in this article, unless otherwise stated in a credit line to the data. 


\section{Background}

Risk Evaluation and Mitigation Strategies (REMS) are a drug safety program required by the US Food and Drug Administration (FDA) for certain medications with serious safety concerns to help ensure that the benefits of a medication outweigh its risks [1]. REMS are required when additional strategies beyond product labeling are needed to reduce the occurrence and/or severity of a specific risk to reinforce the medication's safe use conditions and behaviors [2]. Between 2014 and 2018, approximately $4 \%$ of all drugs and biologics were approved on the condition of having a REMS [3, 4].

Table 1 presents a general REMS program overview. REMS programs address a specific drug-safety situation and risk mitigation goal, such as, preventing, decreasing the frequency or severity of the serious risk, and/or screening for the risk [5]. Pharmaceutical manufacturers (i.e., sponsors) are required to implement REMS programs based on FDA requirements and healthcare settings and providers need to adopt these requirements. REMS activities, as defined by FDA's regulatory authority, can include complex multi-level interventions known as elements to assure safe use (ETASU). Some ETASU target healthcare professionals and healthcare settings, requiring them to be certified to administer and dispense the medication or restrict the dispensing of a medication to a certain setting. Other ETASU may also include monitoring of patients, enrollment of patients in a registry, or certain packaging and safe disposal technologies. Approximately $80 \%$ of currently active REMS include at least one ETASU [6]. In addition to ETASU, other REMS strategies include dissemination of information such as materials in patient-friendly language delivered to patients (Medication Guide, Patient Package
Insert) and communication materials to healthcare providers (Communication Plan) [7, 8].

Program assessment is required for all REMS approved for drugs or biologics under New Drug Applications (NDA) and Biologics License Applications (BLA) and encompasses program participation, outcome and impact measures. Sponsors are required to conduct assessments of each REMS program and provide them to the Agency at defined timetables to determine whether the REMS is meeting its risk mitigation $\operatorname{goal}(\mathrm{s})[1,9]$. These reports should provide information and data that are based on the REMS assessment plan, which is a list of metrics on outreach and communications, knowledge, safe use behaviors, implementation and operations, and health outcomes that drug sponsors need to address. While the statute requires a timetable for submission of an assessment of the REMS, it does not specify how those assessments should be conducted [10].

Since the REMS authorities went into effect in 2008, there has been increased focus on the standardization of REMS assessments. In 2013, the Office of Inspector General (OIG) report urged the FDA to "identify and implement reliable methods to assess the effectiveness of REMS." [11] In that same year, FDA hosted a Standardizing and Evaluating REMS Public Meeting under its Prescription Drug User Fee Act (PDUFA) V commitments to obtain input on working towards "an evidencebased approach to assessing the effectiveness and burden of REMS" and "to identify best practices to incorporate into future REMS design, as well as appropriate ways to standardize REMS tools and integrate REMS into the health care delivery system." [12] In January 2019, the draft guidance for industry on REMS Assessment: Planning and Reporting (henceforth referred to as the Assessment Guidance) calls upon "applicants and the research

Table 1 REMS Program Overview

\begin{tabular}{|c|c|c|c|c|}
\hline Goal & Stakeholders & REMS Intervention & Process Assessment & Outcome Assessment \\
\hline $\begin{array}{l}\text { - Drug safety } \\
\text { risk assessment } \\
\text { and mitigation }\end{array}$ & $\begin{array}{l}\text { - FDA: regulatory } \\
\text { requirements and guidance } \\
\text { - Pharmaceutical } \\
\text { manufacturers: } \\
\text { implementation and } \\
\text { assessment requirements } \\
\text { - Health care settings/ } \\
\text { providers: adoption and risk } \\
\text { mitigation delivery } \\
\text { - Patient/caregiver: program } \\
\text { recipient }\end{array}$ & $\begin{array}{l}\text { Intervention strategies, as } \\
\text { specified by FDA REMS authority: } \\
\text { - Medication Guide (patient } \\
\text { communication) } \\
\text { - Communication Plan (health } \\
\text { care provider communication) } \\
\text { - Elements to Assure Safe Use } \\
\text { - Certification or specialized } \\
\text { training, prescriber } \\
\text { - Certification or specialized } \\
\text { training, pharmacy or other } \\
\text { dispensing setting } \\
\text { - Dispensing/drug administration } \\
\text { requirement, limited settings } \\
\text { - Dispensing/drug administration } \\
\text { requirement, evidence of safe- } \\
\text { use conditions being met } \\
\text { - Patient, monitoring } \\
\text { requirement } \\
\text { - Patient, registry enrollment }\end{array}$ & $\begin{array}{l}\text { REMS participation assessment } \\
\text { category, as defined by FDA } \\
\text { draft Guidance to Industry: } \\
\text { - Program Outreach and } \\
\text { Communication } \\
\text { - Program Implementation and } \\
\text { Operations }\end{array}$ & $\begin{array}{l}\text { REMS outcome assessment } \\
\text { category, as defined by FDA } \\
\text { draft Guidance to Industry: } \\
\text { - Knowledge } \\
\text { - Safe Use Behavior } \\
\text { - Health Outcomes and/or } \\
\text { Surrogate Health Outcomes } \\
\text { Other impact considerations: } \\
\text { - Burden on the health care } \\
\text { delivery system } \\
\text { - Barriers to patient access }\end{array}$ \\
\hline
\end{tabular}


community to develop novel methods for assessing REMS." [8].

Implementation science has been widely applied to health related research to support large-scale evaluations of evidence-based practices and organizational interventions in real-world settings [13]. FDA-mandated drug safety programs similarly seek to integrate processes into the larger healthcare system by targeting individual behaviors and organizational activities; implementation science can lend its theories, frameworks, and research to the more narrowly focused field of pharmaceutical regulation. Viewed through a regulatory risk management lens, implementation is analogous to risk mitigation. Implementation frameworks provide a visual display of a program to help guide one's thinking and development of the program. The current landscape presents an opportune time to continue the progress made and borrow from the field of implementation science to advance the science of REMS assessment and the field of pharmaceutical risk management [14, 15]. Since 2014, Smith and Morrato have argued that minimal attention to frameworks in the design of risk minimization programs has hampered the identification of factors contributing to their success $[14,15]$.

Previous work in recent years have called for increased transparency and standardization of the evaluation of pharmaceutical risk minimization programs. Members of the International Society for Pharmacoepidemiology, Smith et al. used principles from public health intervention design and evaluation to develop a quality reporting checklist informed by a framework from program theory and process evaluation [16]. The resulting RIMES statement is usable for regulators and the pharmaceutical industry and emphasizes the utility of similar standardized reporting to design higher-quality risk minimization evaluation studies and ultimately improve the quality and effectiveness of risk minimization programs. More globally, the European Medicines Agency has continued publishing guidelines on risk minimization measures (RMMs) specific to evaluating the effectiveness of outcomes identified. These discuss qualitative and quantitative data sources and methodologies [17].

The purpose of this research is to evaluate three different implementation science frameworks and their applicability for REMS assessments. This work expands on previous research characterizing REMS assessment plans [18], by comparing and contrasting additional frameworks and by expanding the analysis to include Shared System REMS involving multiple application holders including generics (abbreviated new drug applications or ANDAs). The aim of this structured analysis is to advance the science of REMS assessment and promote the uptake of a scientific approach for program design and evaluation of global pharmaceutical risk management plans. Furthermore, this research has implications for the FDA to consider the application of implementation science frameworks when finalizing its REMS assessment guidance.

\section{Methods}

\section{Selection of frameworks}

Selection of eligible frameworks was done through a repository of dissemination and implementation frameworks found through the NIH's Office of Disease Prevention at dissemination-implementation.org [19]. One member of the research team (LH) defined criteria for selecting frameworks with most effective applicability to REMS. Frameworks had to be in the fields of health, public health, or health services. Because REMS programs encompass risk mitigation strategies, frameworks were selected if they focused on either implementation alone or dissemination and implementation equally. Due to the nature of most REMS programs as multi-level interventions, frameworks also had to characterize the individual, organization, and/or community levels. To operationalize these frameworks into a REMS context, it was appropriate for them to score at least a ' 3 ' out of 5 on construct flexibility, with a ' 1 ' being broad or flexible in definition and a ' 5 ' being detailed with step-by-step actions. Finally, as REMS are FDA-required programs, it was also appropriate to select frameworks that were United States-based.

Five frameworks met inclusion criteria, with two of them being derivations of another two. To select the most applicable frameworks for our research, we narrowed these five down to the top three that were most well-established and supported in the literature, each representing different schools of thought. The resulting frameworks are as follows: RE-AIM (Reach, Effectiveness, Adoption, Implementation, Maintenance) from implementation science, PRECEDE-PROCEED (Predisposing, Reinforcing Enabling, Construct in, Educational, Diagnosis and Evaluation - Policy, Regulatory, Organizational, Construct in, Educational and Environmental, Development) from health program planning and evaluation, and CFIR (Consolidated Framework for Implementation Research) from clinical quality improvement [20-22].

To identify current initiatives in the space intersecting implementation science and risk management, a literature review was conducted in January 2019 to search for articles relating REMS to dissemination and implementation science frameworks using three databases: PubMed, Web of Science, and EMBASE. The database searches were updated August 2020. We inputted search strings consisting of common implementation science and REMS terminology. Examples of these search strings include "risk evaluation and mitigation strategies" AND 
"implementation framework." A more complete list of these terms can be found in Additional file 1. In January 2019, these searches produced no articles and only one abstract relating RE-AIM to a specific REMS program [23]. The updated August 2020 search produced one article [18].

\section{Application of frameworks to REMS assessment plans}

A content analysis of REMS assessment plans was conducted for REMS programs approved by the FDA between 1/1/2014-12/31/2018 [24]. With the first REMS approved in 2008, this timeframe was selected to align with more current REMS approvals. REMS assessment plans were eligible if they were: (1) for a new drug application (NDA) or a biologics license application (BLA) and (2) included ETASU (Table 2). Shared System REMS, which reflect multiple products, including generics, of the same class or molecular moiety under two or more sponsors [25] were included in the analysis. However, REMS comprised of only Communication Plans and/or Medication Guides were excluded from our analysis due to our focus on complex, multi-level, multi-system interventions. REMS assessment plans can be publicly accessed for individual programs through the REMS@FDA website, which link to the Drugs@FDA website, where each drug approval letter containing a list of metrics for the REMS can be found. The unit of analysis of this research focused on REMS assessment items as they are metrics for evaluating the performance of a REMS towards meeting its risk mitigation goals.

Starting with the RE-AIM framework, three reviewers (LH, GT, EM) created construct definitions applicable to REMS assessments by adapting from RE-AIM dimensions defined by the framework (Table 3). After adjudicating these applications for three randomly selected plans (IRR $=75 \%$ ), the review team then refined the definitions accordingly. Two reviewers (LH and GT) categorized each assessment item $(n=674)$ for the remaining 20 plans. This adaptation, adjudication, and refinement process was repeated for PRECEDE-PROCEED (IRR = $79 \%$ ) and CFIR (IRR $=84 \%$ ) (Tables 4, 5 and 6).

Shortly following the initiation of this research, the draft Assessment Guidance was published in January 2019 [8]. This draft Assessment Guidance outlined five categories that were intended to capture REMS program outcomes and processes. To evaluate the utility of the three frameworks on REMS assessments, these RE-AIM dimensions, PRECEDE-PROCEED phases, and CFIR constructs were then mapped to the Assessment Guidance categories: Program Outreach and Communication, Program Implementation and Operations, Knowledge, Safe Use Behaviors, and Health Outcomes and/or Surrogates of Health Outcomes (Additional file 2). For simplicity, the dimensions of RE-AIM, phases of PRECEDE-
PROCEED, and constructs of CFIR will be collectively referred to as "constructs" hereafter. Because REMS programs are focused on achieving its goals through information, education, and/or reinforcement of actions, it was appropriate for us to combine knowledge and safe use behaviors into one assessment category to map to the constructs.

Results were reported as aggregate summary statistics for the frequency distribution across all programs and the number of assessment measures per Assessment Guidance category. Finally, sensitivity analysis was performed to examine qualitative differences by type of application (e.g., drug vs. biologic), type of ETASU, and trends over time. A subgroup analysis for Shared Systems was done in particular. For each framework, descriptive statistics were calculated to determine the proportions each construct was represented per REMS program. Each construct was analyzed for the number of REMS programs addressing the construct, the median number and range of measures representing that construct per REMS program, and the number of measures representing the construct across all programs. Additionally, each assessment item was assessed for inclusion of the Assessment Guidance categories using the mapping of each frameworks' constructs.

\section{Results}

A total of 23 REMS programs consisting of nine BLAs, nine NDAs, and five Shared Systems were selected for analysis based on the eligibility criteria (Additional file 3). Characteristics of these programs at the time of their original REMS approval can be found in Table 2. Programs requiring a REMS varied by indication, including but not limited to B-cell lymphoma, acute pain requiring an opioid analgesic, and multiple sclerosis. Likewise, the risks intended to be mitigated by the REMS varied widely from neurological toxicities to respiratory depression and death. The number of REMS programs by year ranged from three in 2016 and 2018 to seven in 2017. Assessment measures per REMS program ranged from 8 to 71 , for a total of 674 assessment measures across the 23 programs.

Subgroup analysis of Shared System REMS reveals they account for the minimum and maximum values of the number of assessment measures per REMS program, with emtricitabine tenofovir disoproxil fumarate containing 8 measures and sodium oxybate containing 71 measures. While the fewest number of assessment measures were associated with programs containing only ETASU A, no other associations can be made between ETASUs and assessment measures. REMS approval for Shared Systems mostly occurred in the latter years, with three programs approved in 2017 and one each in 2015 and 2016. This is 
Table 2 Characteristics of selected REMS programs at time of original approval, active January 2019

\begin{tabular}{|c|c|c|c|c|c|c|}
\hline Type & $\begin{array}{l}\text { Drug (active } \\
\text { ingredient) }\end{array}$ & Year & ETASU*** & Indication (Benefit) & $\begin{array}{l}\text { Risk(s) requiring } \\
\text { Risk Mitigation }\end{array}$ & $\begin{array}{l}\text { Number of } \\
\text { Assessment } \\
\text { Items }\end{array}$ \\
\hline \multirow[t]{5}{*}{$\overline{A N D A}$} & Clozapine & 2015 & $\begin{array}{l}A, B, D, E \\
F\end{array}$ & $\begin{array}{l}\text { treatment-resistant schizophrenia; reducing } \\
\text { suicidal behavior in patients with } \\
\text { schizophrenia or schizoaffective disorder }\end{array}$ & Neutropenia & 22 \\
\hline & Alosetron & 2016 & A & $\begin{array}{l}\text { severe diarrhea-prominent irritable bowel syn- } \\
\text { drome in women }\end{array}$ & $\begin{array}{l}\text { Ischemic colitis and serious complications } \\
\text { of constipation }\end{array}$ & 10 \\
\hline & $\begin{array}{l}\text { Sodium } \\
\text { Oxybate }\end{array}$ & 2017 & $\begin{array}{l}A, B, D \\
(M G)\end{array}$ & $\begin{array}{l}\text { treatment of cataplexy or excessive daytime } \\
\text { sleepiness in narcolepsy }\end{array}$ & $\begin{array}{l}\text { Serious adverse outcomes resulting from } \\
\text { inappropriate prescribing, misuse, abuse, } \\
\text { and diversion }\end{array}$ & 71 \\
\hline & Vigabatrin & 2017 & $A, B, D, E$ & $\begin{array}{l}\text { treatment of refractory complex partial seizures } \\
\text { in adults and infantile spasms }\end{array}$ & Vision loss & 23 \\
\hline & $\begin{array}{l}\text { Emtricitabine/ } \\
\text { Tenofovir } \\
\text { Disoproxil } \\
\text { Fumarate }\end{array}$ & 2017 & A & treatment of HIV-1 infection & Acquiring HIV-1 infection & 8 \\
\hline \multirow[t]{9}{*}{ BLA } & $\begin{array}{l}\text { Myalept } \\
\text { (metreleptin) }\end{array}$ & 2014 & $A, B, D$ & $\begin{array}{l}\text { treat the complications of leptin deficiency in } \\
\text { patients with congenital or acquired } \\
\text { generalized lipodystrophy }\end{array}$ & $\begin{array}{l}\text { Lymphoma \& anti-metreleptin antibodies } \\
\text { that neutralize endogenous leptin and/or } \\
\text { Myalept }\end{array}$ & 26 \\
\hline & $\begin{array}{l}\text { Lemtrada } \\
\text { (alemtuzumab) }\end{array}$ & 2014 & $\begin{array}{l}\text { A, B, C, D } \\
\text { (CP) }\end{array}$ & $\begin{array}{l}\text { treatment of patients with relapsing forms of } \\
\text { multiple sclerosis }\end{array}$ & $\begin{array}{l}\text { Autoimmune conditions, infusion } \\
\text { reactions, and malignancies }\end{array}$ & 36 \\
\hline & $\begin{array}{l}\text { Natpara } \\
\text { (parathyroid } \\
\text { hormone) }\end{array}$ & 2015 & $A, B, D$ & $\begin{array}{l}\text { an adjunct to calcium and vitamin D to control } \\
\text { hypocalcemia in patients with } \\
\text { hypoparathyroidism }\end{array}$ & Osteosarcoma & 21 \\
\hline & $\begin{array}{l}\text { Zinbryta } \\
\text { (daclizumab) }\end{array}$ & 2017 & $\begin{array}{l}A, B, D, E \\
F(C P)\end{array}$ & $\begin{array}{l}\text { treatment of adult patients with relapsing } \\
\text { forms of multiple sclerosis }\end{array}$ & $\begin{array}{l}\text { Hepatic injury \& immune mediated } \\
\text { disorders }\end{array}$ & 27 \\
\hline & $\begin{array}{l}\text { Siliq } \\
\text { (brodalumab) }\end{array}$ & 2017 & $A, B, D$ & $\begin{array}{l}\text { treatment of moderate to severe plaque } \\
\text { psoriasis in adult patients who are candidates } \\
\text { for systemic therapy or phototherapy and have } \\
\text { failed to respond or have lost response to } \\
\text { other systemic therapies }\end{array}$ & $\begin{array}{l}\text { Suicidal ideation and behavior, including } \\
\text { completed suicides }\end{array}$ & 31 \\
\hline & $\begin{array}{l}\text { Kymriah } \\
\text { (tisagenlecleucel) }\end{array}$ & 2017 & $B, C$ & $\begin{array}{l}\text { treatment of: Pediatric and Young Adult } \\
\text { Relapsed or Refractory }(r / r) \text { B-cell Acute } \\
\text { Lymphoblastic Leukemia \& Adult Relapsed or } \\
\text { Refractory }(r / r) \text { Diffuse Large B-Cell Lymphoma }\end{array}$ & $\begin{array}{l}\text { Cytokine release syndrome \& } \\
\text { neurological toxicities }\end{array}$ & 21 \\
\hline & $\begin{array}{l}\text { Yescarta } \\
\text { (axicabtagene } \\
\text { ciloleucel) }\end{array}$ & 2017 & $B, C$ & $\begin{array}{l}\text { treatment of adult patients with relapsed or } \\
\text { refractory large B-cell lymphoma after two or } \\
\text { more lines of systemic therapy }\end{array}$ & $\begin{array}{l}\text { Cytokine release syndrome \& } \\
\text { neurological toxicities }\end{array}$ & 21 \\
\hline & $\begin{array}{l}\text { Palynziq } \\
\text { (pegvaliase- } \\
\text { pqpz) }\end{array}$ & 2018 & $A, B, D$ & $\begin{array}{l}\text { reduce blood phenylalanine concentrations in } \\
\text { adult patients with phenylketonuria who have } \\
\text { uncontrolled blood phenylalanine } \\
\text { concentrations greater than } 600 \text { micromol/L } \\
\text { on existing management }\end{array}$ & Anaphylaxis & 31 \\
\hline & $\begin{array}{l}\text { Ultomiris } \\
\text { (ravulizumab- } \\
\text { cWVz) }\end{array}$ & 2018 & A & $\begin{array}{l}\text { treatment of adult patients with paroxysmal } \\
\text { nocturnal hemoglobinuria }\end{array}$ & Meningococcal infections & 10 \\
\hline \multirow[t]{4}{*}{ NDA } & $\begin{array}{l}\text { Aveed } \\
\text { (testosterone } \\
\text { undecanoate) }\end{array}$ & 2014 & $A, B, C$ & $\begin{array}{l}\text { testosterone replacement therapy in adult } \\
\text { males for conditions associated with a } \\
\text { deficiency or absence of endogenous } \\
\text { testosterone }\end{array}$ & $\begin{array}{l}\text { Autoimmune conditions, infusion } \\
\text { reactions, and malignancies }\end{array}$ & 36 \\
\hline & $\begin{array}{l}\text { Xyrem } \\
\text { (Sodium } \\
\text { oxybate) }\end{array}$ & 2015 & $\begin{array}{l}A, B, D \\
(M G)\end{array}$ & $\begin{array}{l}\text { treatment of cataplexy or excessive daytime } \\
\text { sleepiness in patients } 7 \text { years of age and older } \\
\text { with narcolepsy }\end{array}$ & $\begin{array}{l}\text { Serious adverse outcomes resulting from } \\
\text { inappropriate prescribing, misuse, abuse, } \\
\text { and diversion }\end{array}$ & 57 \\
\hline & $\begin{array}{l}\text { lonsys } \\
\text { (fentanyl } \\
\text { iontophoretic) } \\
\text { transdermal } \\
\text { system) }\end{array}$ & 2015 & $B, C$ & $\begin{array}{l}\text { short-term management of acute } \\
\text { postoperative pain severe enough to require } \\
\text { an opioid analgesic in the hospital and for } \\
\text { which alternative treatments are inadequate }\end{array}$ & $\begin{array}{l}\text { Respiratory depression resulting from } \\
\text { accidental exposure }\end{array}$ & 29 \\
\hline & Addyi & 2015 & $A, B$ & treatment of premenopausal women with & Hypotension and syncope due to & 32 \\
\hline
\end{tabular}


Table 2 Characteristics of selected REMS programs at time of original approval, active January 2019 (Continued)

\begin{tabular}{|c|c|c|c|c|c|c|}
\hline Type & $\begin{array}{l}\text { Drug (active } \\
\text { ingredient) }^{* *}\end{array}$ & Year & ETASU*** & Indication (Benefit) & $\begin{array}{l}\text { Risk(s) requiring } \\
\text { Risk Mitigation }\end{array}$ & $\begin{array}{l}\text { Number of } \\
\text { Assessmen } \\
\text { Items }\end{array}$ \\
\hline & (flibanserin) & & & $\begin{array}{l}\text { acquired, generalized hypoactive sexual desire } \\
\text { disorder, as characterized by low sexual desire } \\
\text { that causes marked distress or interpersonal } \\
\text { difficulty }\end{array}$ & interaction with alcohol & \\
\hline & $\begin{array}{l}\text { Probuphine } \\
\text { (buprenorphine } \\
\text { hydrochloride) }\end{array}$ & 2016 & $\begin{array}{l}A, B, C, E \\
(M G)\end{array}$ & $\begin{array}{l}\text { maintenance treatment of opioid dependence } \\
\text { in patients who have achieved and sustained } \\
\text { prolonged clinical stability on low-to-moderate } \\
\text { doses of a transmucosal buprenorphine- } \\
\text { containing product }\end{array}$ & $\begin{array}{l}\text { Migration, protrusion, expulsion and } \\
\text { nerve damage associated with insertion } \\
\text { and removal \& accidental overdose, } \\
\text { misuse and abuse }\end{array}$ & 22 \\
\hline & $\begin{array}{l}\text { Sublocade } \\
\text { (buprenorphine } \\
\text { extended- } \\
\text { release) }\end{array}$ & 2017 & B & $\begin{array}{l}\text { treatment of moderate to severe opioid use } \\
\text { disorder in patients who have initiated } \\
\text { treatment with a transmucosal buprenorphine- } \\
\text { containing product, followed by dose adjust- } \\
\text { ment for a minimum of } 7 \text { days }\end{array}$ & Intravenous self-administration & 20 \\
\hline & $\begin{array}{l}\text { Jynarque } \\
\text { (tolvaptan) }\end{array}$ & 2018 & $\begin{array}{l}A, B, D, E \\
F(C P)\end{array}$ & $\begin{array}{l}\text { slow kidney function decline in adults at risk of } \\
\text { rapidly progressing autosomal dominant } \\
\text { polycystic kidney disease }\end{array}$ & Liver injury & 42 \\
\hline & $\begin{array}{l}\text { Tegsedi } \\
\text { (Inotersen) }\end{array}$ & 2018 & $\begin{array}{l}A, B, D, E \\
F\end{array}$ & $\begin{array}{l}\text { treatment of polyneuropathy of hereditary } \\
\text { transthyretin-mediated amyloidosis in adults }\end{array}$ & $\begin{array}{l}\text { Bleeding with thrombocytopenia \& } \\
\text { glomerulonephritis }\end{array}$ & 57 \\
\hline & $\begin{array}{l}\text { Dsuvia } \\
\text { (sufentanil) }\end{array}$ & 2018 & $B, C$ & $\begin{array}{l}\text { use in adults in certified medically supervised } \\
\text { healthcare settings for the management of } \\
\text { acute pain severe enough to require an opioid } \\
\text { analgesic and for which alternative treatments } \\
\text { are inadequate }\end{array}$ & $\begin{array}{l}\text { Respiratory depression from accidental } \\
\text { exposure }\end{array}$ & 35 \\
\hline
\end{tabular}

ANDA, Abbreviated New Drug Application; BLA, Biologic License Application; NDA, New Drug Application; ETASU, Elements to Assure Safe Use; CP,

Communication Plan; MG, Medication Guide

** REMS programs were selected January 2019

***ETASU A, training or certification of prescribers; ETASU B, training or certification of dispensers; ETASU C, dispensing/administering the drug in certain settings; ETASU D, requiring evidence or documentation of safe use conditions; ETASU E, monitoring of patients; ETASU $F$, enrolling patients in a registry

Data source: Food and Drug Administration. Approved Risk Evaluation and Mitigation Strategies (REMS). Available from: https:/www.accessdata.fda.gov/scripts/

cder/rems/index.cfm (REMS@FDA). Also available from Drugs@FDA

reasonable because Shared System REMS reflect sustaining programs requiring multiple sponsors of the reference listed drug and ANDA to work together on the design and development of the REMS, a process requiring a substantial amount of time.

\section{Insights from the application of RE-AIM to REMS}

From the participating pool of stakeholders comprised of patients, healthcare providers, pharmacies, wholesalers/distributors, and healthcare setting, defining REAIM constructs for application to REMS required the agent and recipient of the program to be identified. Recipients refer to patients or other populations who are targeted to benefit from the program outcomes produced, while agents are defined as people who deliver the program. Others have applied effectiveness to providers and the healthcare setting as well as implementation to patients $[23,26]$. For our analysis, we defined patients as the recipients of the REMS program and providers, pharmacies, and wholesalers as the agents. Subsequently, the Reach and Effectiveness constructs applied to patients, Adoption and Implementation to providers/ pharmacies/wholesalers, and Maintenance to any participant.
REMS assessment measures demonstrated the strongest congruence with the RE-AIM framework. All five RE-AIM constructs were represented with REMS assessment measures. Of 674 assessment measures across the 23 programs, only 4 measures $(0.6 \%)$ could not be mapped to a single RE-AIM construct because either the intent of the assessment item was unclear or there were multiple intents of the assessment item, making it categorizable into multiple constructs. For example, we defined Reach to refer to the number of patients eligible to receive the drug who participate in the program and Adoption to refer to the number of agents (e.g., prescribers) involved in adopting and implementing the program (Table 3). Therefore, items assessing the number of prescriptions in compliance with REMS requirements were too ambiguous to classify to a single REMS domain because prescriptions could either reflect prescriber-compliant participation in the program through prescriber certification (Adoption) or the number of patients who ultimately received the medication (Reach).

Of 23 total REMS assessment plans, 19 (82.6\%) contained measures assessing Reach, with the median number of Reach assessment measures per assessment plan 
Table 3 Adaptation of RE-AIM dimensions as applied to REMS assessment measures and Assessment Guidance categories

\begin{tabular}{|c|c|c|c|c|}
\hline $\begin{array}{l}\text { RE-AIM } \\
\text { Dimension }\end{array}$ & General Description* & $\begin{array}{l}\text { Description as Applied to REMS } \\
\text { Assessments** }\end{array}$ & $\begin{array}{l}\text { Assessment } \\
\text { Guidance } \\
\text { Category }\end{array}$ & $\begin{array}{l}\text { Definitions of Assessment } \\
\text { Guidance Category }\end{array}$ \\
\hline Reach & $\begin{array}{l}\text { Reach refers to the absolute } \\
\text { number, proportion, and } \\
\text { representativeness of individuals } \\
\text { who are willing to participate in a } \\
\text { given initiative, intervention, or } \\
\text { program }\end{array}$ & $\begin{array}{l}\text { Patient (individual level) } \\
\text { - Number of patients treated or } \\
\text { enrolled (numerator) } \\
\text { - Proportion of eligible patients } \\
\text { ("valid denominator" given the } \\
\text { drug's indicated use) treated or } \\
\text { enrolled } \\
\text { - Characteristics of patients treated } \\
\text { or enrolled compared with } \\
\text { nonparticipants - } \\
\text { representativeness }\end{array}$ & $\begin{array}{l}\text { Outreach and } \\
\text { Communications }\end{array}$ & $\begin{array}{l}\text { Measures of the extent to which } \\
\text { the REMS materials reached the } \\
\text { intended stakeholders }\end{array}$ \\
\hline Effectiveness & $\begin{array}{l}\text { Effectiveness refers to the impact of } \\
\text { an intervention on important } \\
\text { outcomes, including potential } \\
\text { negative effects, quality of life, and } \\
\text { economic outcomes }\end{array}$ & $\begin{array}{l}\text { Patient (individual level) } \\
\text { - Knowledge-Attitudes; Process- } \\
\text { Behavior; Health Outcomes and/or } \\
\text { Surrogates } \\
\text { - Positive and negative (unintended) } \\
\text { impacts; observed vs. expected } \\
\text { rates of effectiveness } \\
\text { - Heterogeneity (variability) of effect } \\
\text { across different subpopulations }\end{array}$ & $\begin{array}{l}\text { Safe Use } \\
\text { Behaviors and } \\
\text { Knowledge } \\
\text { Health } \\
\text { Outcomes }\end{array}$ & $\begin{array}{l}\text { Measures of the extent to which } \\
\text { safe use conditions are being } \\
\text { adopted or followed, or of } \\
\text { stakeholders' knowledge about the } \\
\text { REMS-related risk or knowledge of } \\
\text { any safe use conditions } \\
\text { Measures of the safety-related } \\
\text { health outcome of interest or a sur- } \\
\text { rogate of a health outcome }\end{array}$ \\
\hline Adoption & $\begin{array}{l}\text { Adoption refers to the absolute } \\
\text { number, proportion, and } \\
\text { representativeness of settings and } \\
\text { intervention agents (people who } \\
\text { deliver the program) who are } \\
\text { willing to initiate the program }\end{array}$ & $\begin{array}{l}\text { Health Care System (setting level) } \\
\text { - Number of practices, clinics, } \\
\text { hospitals or pharmacies certified or } \\
\text { enrolled (numerator) } \\
\text { - Proportion of eligible practices, } \\
\text { clinics, hospitals or pharmacies } \\
\text { ("valid denominator" given the } \\
\text { drug's indicated use) certified or } \\
\text { enrolled } \\
\text { - Characteristics of practices, clinics, } \\
\text { hospitals or pharmacies certified or } \\
\text { enrolled compared with non- } \\
\text { adopters - representativeness } \\
\text { Health Care Provider (agent level) } \\
\text { - Number of prescribers and/or } \\
\text { pharmacists certified or enrolled } \\
\text { (numerator) } \\
\text { - Proportion of eligible prescribers } \\
\text { and/or pharmacists ("valid } \\
\text { denominator" given the drug's } \\
\text { indicated use) certified or enrolled } \\
\text { - Characteristics of prescribers and/or } \\
\text { pharmacists certified or enrolled } \\
\text { compared with non-adopters - } \\
\text { representativeness }\end{array}$ & $\begin{array}{l}\text { Outreach and } \\
\text { Communications }\end{array}$ & $\begin{array}{l}\text { Measures of the extent to which } \\
\text { the REMS materials reached the } \\
\text { intended stakeholders }\end{array}$ \\
\hline \multirow[t]{2}{*}{ Implementation } & \multirow[t]{2}{*}{$\begin{array}{l}\text { At the setting level, implementation } \\
\text { refers to the intervention agents' } \\
\text { fidelity to the various elements of } \\
\text { an intervention's protocol, including } \\
\text { consistency of delivery as intended } \\
\text { and the time and cost of the } \\
\text { intervention } \\
\text { Implementation elements include: } \\
\text { implementation fidelity, adaptation, } \\
\text { and cost of intervention } \\
\text { At the agent level, implementation } \\
\text { refers to the clients' use of the } \\
\text { intervention strategies }\end{array}$} & $\begin{array}{l}\text { Health Care System (setting level) } \\
\text { - Percent of targeted groups who } \\
\text { were sent, received REMS } \\
\text { information and/or training (by } \\
\text { mode and frequency of } \\
\text { distribution) } \\
\text { - Curriculum consistency - fidelity } \\
\text { and adaptation over time (by } \\
\text { training modality) } \\
\text { - Extent of completed, successful } \\
\text { training and/or certification in the } \\
\text { program } \\
\text { - Incremental costs and resources } \\
\text { required (fixed and variable) for } \\
\text { REMS participation } \\
\text { - Heterogeneity (variability) of } \\
\text { implementation across different } \\
\text { settings }\end{array}$ & $\begin{array}{l}\text { Implementation } \\
\text { and Operations }\end{array}$ & $\begin{array}{l}\text { Measures of the extent to which } \\
\text { the intended stakeholders are } \\
\text { participating in the program, how } \\
\text { effectively the REMS program is } \\
\text { being implemented and any } \\
\text { unintended consequences such as } \\
\text { patient access or burden to the } \\
\text { healthcare system }\end{array}$ \\
\hline & & Health Care Provider (agent level) & Safe Use & Measures of the extent to which \\
\hline
\end{tabular}


Table 3 Adaptation of RE-AIM dimensions as applied to REMS assessment measures and Assessment Guidance categories (Continued)

\begin{tabular}{|c|c|c|c|c|}
\hline $\begin{array}{l}\text { RE-AIM } \\
\text { Dimension }\end{array}$ & General Description* & $\begin{array}{l}\text { Description as Applied to REMS } \\
\text { Assessments** }\end{array}$ & $\begin{array}{l}\text { Assessment } \\
\text { Guidance } \\
\text { Category }\end{array}$ & $\begin{array}{l}\text { Definitions of Assessment } \\
\text { Guidance Category }\end{array}$ \\
\hline & & $\begin{array}{l}\text { - Educational effectiveness } \\
\text { measured by: knowledge-attitudes, } \\
\text { behavioral intention for safe use pro- } \\
\text { cesses and procedures, observed } \\
\text { behavior-compliance } \\
\text { - Heterogeneity (variability) of } \\
\text { implementation across different } \\
\text { settings and/or provider } \\
\text { characteristics }\end{array}$ & $\begin{array}{l}\text { Behaviors and } \\
\text { Knowledge }\end{array}$ & $\begin{array}{l}\text { safe use conditions are being } \\
\text { adopted or followed, or of } \\
\text { stakeholders' knowledge about the } \\
\text { REMS-related risk or knowledge of } \\
\text { any safe use conditions }\end{array}$ \\
\hline \multirow[t]{2}{*}{ Maintenance } & $\begin{array}{l}\text { At the setting level, maintenance } \\
\text { reflects the extent to which the } \\
\text { program or processes become } \\
\text { institutionalized or sustained as part } \\
\text { of routine practice over time }\end{array}$ & $\begin{array}{l}\text { Health Care System (setting level) } \\
\text { - Cumulative real-world evidence of } \\
\text { the integration of REMS processes } \\
\text { and procedures into state and insti- } \\
\text { tutional policies, treatment guide- } \\
\text { lines, insurance requirements }\end{array}$ & Not included & Not applicable \\
\hline & $\begin{array}{l}\text { At the agent or individual level, } \\
\text { maintenance reflects the extent to } \\
\text { which practices become a stable } \\
\text { part of the behavioral repertoire of } \\
\text { the individual }\end{array}$ & $\begin{array}{l}\text { Health Care Provider (agent level) } \\
\text { \& Patient (individual level) } \\
\text { - Cumulative evidence over time to } \\
\text { include: durability of knowledge; } \\
\text { compliance with REMS processes } \\
\text { and procedures; attrition rate (from } \\
\text { the program); heterogeneity } \\
\text { (variability) of attrition by } \\
\text { subgroups, unintended outcomes, } \\
\text { e.g., access or burden issues }\end{array}$ & Not included & Not applicable \\
\hline
\end{tabular}

Not included: no appropriate category from the Assessment Guidance. Not applicable: not currently assessed in the REMS program to have application *Defined in Gaglio B SJ, Glasgow RE. The RE-AIM Framework: A Systematic Review of Use Over Time. American Journal of Public Health (AJPH) (2013) 103(6):38-46 **Informed by the National Cancer Institute. RE-AIM Scoring Instrument [updated 09/04/2013]. Available from: https://rtips.cancer.gov/rtips/reAim.do

being 2 (range 0-7). For Effectiveness, 20 (87.0\%) REMS assessment plans included this construct, with the median number of assessment measures per plan being 2 (range 0-9). All 23 (100\%) REMS assessment plans measured Adoption, with the median number of assessment measures per plan being 3 (range 0-7). Similarly, all 23 (100\%) assessment plans also measured Implementation, however with a median number of assessment measures per plan being 18 (range 4-52). Finally, only 9 of 23 programs (39.1\%) contained assessment measures of Maintenance, with the median number of assessment measures per plan being 0 (range $0-1$ ).

Similarly, the median number of Reach assessment measures per Shared System assessment plan was also 2 (range 0-4). Notably, the Shared System REMS for emtricitabine tenofovir disoproxil fumarate contained the highest proportion of measures assessing Effectiveness, with this construct accounting for $37.5 \%$ of all assessment items. Adoption was similarly assessed among the Shared System REMS with the median number of assessment measures being 1 (range 1-5). The assessment of Implementation measures among Shared System REMS was comparable to that of other REMS programs, with the median number being 14 (range 4-52). Similar to the scarcity of other programs, only 1 Shared System REMS contained assessment measures of Maintenance, with the median number of assessment measures per plan being 0 (range 0-1). Shared System REMS shared the median number of Maintenance assessment measures compared to other programs, with this figure being 0 (range $0-1$ ).

Categorizing the REMS assessment measures to the Assessment Guidance was also a feasible task (Fig. 1). Measures of Reach and Adoption were categorizable to Outreach and Communications, depending on whether the patient or provider was targeted. Those of Effectiveness were mapped to Health Outcomes if the item assessed adverse events or health risks and to Safe Use Behaviors and Knowledge if the item assessed patients' understanding of the risks. Similarly, REMS assessment measures falling into the RE-AIM Implementation construct were categorizable to the Assessment Guidance's Implementation and Operations category if they were process measures and into Safe Use Behaviors and Knowledge if they assessed providers/pharmacists' understanding of the risks. Finally, although the Assessment Guidance does not include Maintenance as a category, some programs included a measure of Maintenance on their assessment plans. 
Table 4 Adaptation of PRECEDE-PROCEED phases as applied to REMS assessment measures and Assessment Guidance categories. Predisposing, Reinforcing, and Enabling Constructs in Educational / Ecological Diagnosis and Evaluation (PRECEDE Structure)

\begin{tabular}{|c|c|c|c|c|}
\hline PRECEDE Phase & General Description & $\begin{array}{l}\text { Description as Applied to } \\
\text { REMS Assessments }\end{array}$ & $\begin{array}{l}\text { Assessment } \\
\text { Guidance } \\
\text { Category }\end{array}$ & $\begin{array}{l}\text { Definitions of } \\
\text { Assessment } \\
\text { Guidance } \\
\text { Categories }\end{array}$ \\
\hline 1. Social Assessment & $\begin{array}{l}\text { Determine what the target population wants } \\
\text { and the ultimate desired result. Identify } \\
\text { specific health problems that may contribute } \\
\text { to the target population's quality of life, social } \\
\text { goals, or problems; } \\
\text { Diagnose severity of the problem as } \\
\text { perceived by the target population }\end{array}$ & $\begin{array}{l}\text { Summarize the benefit-risk profile of the } \\
\text { drug and unmet medical need } \\
\text { Identify patient health and treatment } \\
\text { preferences for the target patient group } \\
\text { Determine if patients are willing to take on } \\
\text { risks associated with REMS medications in } \\
\text { the context of treatment benefits, ensuring } \\
\text { that they are sufficiently informed to share } \\
\text { decision making and are confident in their } \\
\text { ability to comply with REMS. }\end{array}$ & Not included & Not applicable \\
\hline $\begin{array}{l}\text { 2. Epidemiological } \\
\text { Assessment }\end{array}$ & $\begin{array}{l}\text { Identify the prevalence, health determinants, } \\
\text { and burden of the identified problems; } \\
\text { Set priorities and goals }\end{array}$ & $\begin{array}{l}\text { Benefit-risk assessment that a REMS is } \\
\text { necessary to ensure the benefits outweigh } \\
\text { the risks } \\
\text { Identify the gap in knowledge or aspect of } \\
\text { human behavior that leads to risk (e.g. } \\
\text { alcohol use resulting in an interaction with } \\
\text { the drug) } \\
\text { Epidemiological data of the risks that the } \\
\text { REMS is intended to address } \\
\text { Epidemiological data on the target } \\
\text { population } \\
\text { REMS goal presented in a "SMART" format - } \\
\text { the overall, safety-related health outcome(s) } \\
\text { that the REMS is designed to achieve }\end{array}$ & Not included & Not applicable \\
\hline $\begin{array}{l}\text { 3. Educational and } \\
\text { Ecological } \\
\text { Assessment }\end{array}$ & $\begin{array}{l}\text { Categorize the predisposing, enabling, or } \\
\text { reinforcing factors most likely to result in } \\
\text { behavior change }\end{array}$ & $\begin{array}{l}\text { Identify workflow preferences for the target } \\
\text { healthcare provider } \\
\text { Intermediate, measurable REMS objectives } \\
\text { presented in a "SMART" format } \\
\text { Determine which REMS materials and } \\
\text { Participant Requirements would be most } \\
\text { inducive to achieving goal. } \\
\text { Health literacy \& self-efficacy (ability to do } \\
\text { what is required) }\end{array}$ & Not included & Not applicable \\
\hline $\begin{array}{l}\text { 4. Administrative } \\
\text { and Policy } \\
\text { Assessment and } \\
\text { Intervention } \\
\text { Alignment }\end{array}$ & $\begin{array}{l}\text { Identify administrative, organizational, and } \\
\text { policy factors required for development and } \\
\text { implementation of the intervention as well as } \\
\text { resources and barriers }\end{array}$ & $\begin{array}{l}\text { Identify clinical workflow preferences for the } \\
\text { target healthcare settings } \\
\text { Determine the REMS interventions e.g., } \\
\text { ETASU to achieve objectives or other } \\
\text { Applicant Requirements } \\
\text { Clinical/medical practice guidelines }\end{array}$ & Not included & Not applicable \\
\hline
\end{tabular}

\section{Insights from the application of PRECEDE-PROCEED to} REMS

As a health program planning and evaluation model, PRECEDE-PROCEED provides structures for both specifying objectives and baselines before the intervention as well as for monitoring and continuous quality improvement after the intervention. However, as REMS include implementation and evaluation aspects, we did not apply PRECEDE and only defined the PROCEED constructs as applicable to REMS. Instead, we interpreted the "design intervention" step of the Implementation construct to assume that design assumptions from the PRECEDE constructs are met. This aligns to the nature of the PRECEDE-PROCEED framework, wherein change begins with the outcome, and the process moves backward logically to achieve the desired result in a formative process. Process Evaluation mapped to REMS assessment measures attributable to "the system," while Impact Evaluation mapped measures relating to "the individual." For constructs consisting of multiple components in the original definition, we divided these up into subconstructs when applying the definitions to REMS.

PRECEDE-PROCEED exemplified strong congruence to REMS assessment plans, with seven assessment measures not represented by the framework, as stakeholder engagement is not accessed in the PROCEED constructs. Therefore this $1 \%$ of REMS assessment measures that was not mapped to PRECEDE-PROCEED was related to antecedent outreach factors, such as sources of distribution lists. Not only were all PROCEED constructs represented by REMS assessment measures, but so were all 
Table 5 Policy, Regulatory, and Organizational Constructs in Educational and Environmental Development (PROCEED Structure)

\begin{tabular}{|c|c|c|c|c|}
\hline $\begin{array}{l}\text { PROCEED } \\
\text { Phase }\end{array}$ & General Description & $\begin{array}{l}\text { Description as applied to } \\
\text { REMS Assessments }\end{array}$ & $\begin{array}{l}\text { Assessment } \\
\text { Guidance } \\
\text { Category }\end{array}$ & $\begin{array}{l}\text { Definitions of Assessment } \\
\text { Guidance Categories }\end{array}$ \\
\hline \multirow[t]{3}{*}{$\begin{array}{l}5 . \\
\text { Implementation }\end{array}$} & $\begin{array}{l}\text { Design intervention; } \\
\text { Assess availability of resources; } \\
\text { Implement program }\end{array}$ & $\begin{array}{l}\text { A. REMS Design (PRECEDE } \\
\text { assumptions): } \\
\text { - Alignment with patient } \\
\text { preferences } \\
\text { - Alignment with healthcare } \\
\text { system and clinical workflow } \\
\text { norms } \\
\text { - Alignment with health } \\
\text { insurance requirements and } \\
\text { medical practice guidelines }\end{array}$ & Not included & Not applicable \\
\hline & & $\begin{array}{l}\text { B. Availability of Resources: } \\
\text { - Capacity and capability of the } \\
\text { healthcare personnel to fulfill } \\
\text { REMS requirements (human } \\
\text { resources) } \\
\text { - Availability (costs) of medical } \\
\text { supplies and facilities necessary } \\
\text { to fulfill REMS requirements } \\
\text { (physical resources) }\end{array}$ & Not included & Not applicable \\
\hline & & $\begin{array}{l}\text { C. Program Outreach and } \\
\text { Communication: } \\
\text { - Date of product or REMS } \\
\text { launch } \\
\text { - Date communication materials } \\
\text { distributed (by mode and } \\
\text { frequency, including website } \\
\text { access) } \\
\text { - Dates of training programs (by } \\
\text { mode and frequency) }\end{array}$ & $\begin{array}{l}\text { Program } \\
\text { Outreach and } \\
\text { Communication }\end{array}$ & $\begin{array}{l}\text { Measures of the extent to which the } \\
\text { REMS materials reached the intended } \\
\text { stakeholders }\end{array}$ \\
\hline $\begin{array}{l}\text { 6. Process } \\
\text { Evaluation }\end{array}$ & $\begin{array}{l}\text { Determine whether planned program } \\
\text { put into action has been successfully } \\
\text { implemented in target audience; } \\
\text { Ongoing evaluation and modification } \\
\text { of program components }\end{array}$ & $\begin{array}{l}\text { A. Program Implementation } \\
\text { At the Health Care Setting-, Health } \\
\text { Care Provider- and Patient-Level } \\
\text { - Number successfully certified, } \\
\text { enrolled or receiving the } \\
\text { medication; proportion of target } \\
\text { audience certified or enrolled. }\end{array}$ & $\begin{array}{l}\text { Program } \\
\text { Implementation } \\
\text { and Operations }\end{array}$ & $\begin{array}{l}\text { Measures of the extent to which the } \\
\text { intended stakeholders are } \\
\text { participating in the program, how } \\
\text { effectively the REMS program is being } \\
\text { implemented and any unintended } \\
\text { consequences such as patient access } \\
\text { or burden to the healthcare system }\end{array}$ \\
\hline
\end{tabular}

- Characteristics of those certified enrolled or receiving the medication compared with non-adopters in the same target audience - representativeness

- Unenrollment (voluntary) of health care providers (and reasons)

B. Quality Process Improvement/ System-Level Evaluation (by risk mitigation strategy)

- Unintended interruptions and/ or delays

- Training curriculum fidelity and adaptation (by training modality)

- Audit findings and corrective actions, including analysis of Call Center complaints and

dispensing systems

- Number (type) of REMS modifications

7. Impact Evaluation
Determine effectiveness and efficiency of program in terms of intermediate objectives and change in predisposing, enabling, and reinforcing factors (immediate observable effects of the program);
A. Effectiveness: Knowledge and Skill

At the Health Care Provider- and Patient-Level

- Effectiveness of certification training
Program Implementation and Operations

Knowledge

Measures of the extent of stakeholders' knowledge about the REMS-related risk or knowledge of any safe use conditions that are needed in order to mitigate the risk 
Table 5 Policy, Regulatory, and Organizational Constructs in Educational and Environmental Development (PROCEED Structure)

\begin{tabular}{|c|c|c|c|c|}
\hline $\begin{array}{l}\text { PROCEED } \\
\text { Phase }\end{array}$ & General Description & $\begin{array}{l}\text { Description as applied to } \\
\text { REMS Assessments }\end{array}$ & $\begin{array}{l}\text { Assessment } \\
\text { Guidance } \\
\text { Category }\end{array}$ & $\begin{array}{l}\text { Definitions of Assessment } \\
\text { Guidance Categories }\end{array}$ \\
\hline & \multirow{4}{*}{$\begin{array}{l}\text { examines impact of program } \\
\text { intervention on environmental and } \\
\text { behavioral factors identified in } \\
\text { PRECEDE phase of intervention } \\
\text { design }\end{array}$} & $\begin{array}{l}\text { - Knowledge and awareness of } \\
\text { key risk messages }\end{array}$ & & \\
\hline & & $\begin{array}{l}\text { B. Effectiveness: Compliance } \\
\text { At the Health Care Provider- and } \\
\text { Patient-Level } \\
\text { - Behavioral intention (self- } \\
\text { reported) to take appropriate risk } \\
\text { mitigation or safe use behaviors } \\
\text { - Risk mitigation and safe use } \\
\text { behaviors (observed) } \\
\text { - Decertification (required) of } \\
\text { health care provider (and } \\
\text { reasons) }\end{array}$ & $\begin{array}{l}\text { Evaluation of } \\
\text { Safe Use } \\
\text { Conditions }\end{array}$ & $\begin{array}{l}\text { Measures of the extent to which safe } \\
\text { use conditions are being adopted or } \\
\text { followed }\end{array}$ \\
\hline & & $\begin{array}{l}\text { C. Efficiency } \\
\text { - Evidence of integration into } \\
\text { clinical workflows and perceived } \\
\text { burden given health care } \\
\text { professional preferences } \\
\text { - Patient access and perceived } \\
\text { burden given patient preferences } \\
\text { - Unenrollment (voluntary) of } \\
\text { patients (due to burden) } \\
\text { - Clinical efficiency (e.g., Number } \\
\text { Needed to Screen to mitigate } \\
\text { risk) }\end{array}$ & $\begin{array}{l}\text { Program } \\
\text { Implementation } \\
\text { and Operations }\end{array}$ & $\begin{array}{l}\text { Measures of the extent to which the } \\
\text { intended stakeholders are } \\
\text { participating in the program, how } \\
\text { effectively the REMS program is being } \\
\text { implemented and any unintended } \\
\text { consequences such as patient access } \\
\text { or burden to the healthcare system }\end{array}$ \\
\hline & & $\begin{array}{l}\text { D. Effectiveness: Environmental } \\
\text { Factors } \\
\text { - Change in predisposing, } \\
\text { reinforcing, and enabling } \\
\text { behavioral factors } \\
\text { - Administrative and policy } \\
\text { factors (e.g., treatment guidelines } \\
\text { and insurance prescribing } \\
\text { requirements) }\end{array}$ & Not included & Not applicable \\
\hline $\begin{array}{l}\text { 8. Outcome } \\
\text { Evaluation }\end{array}$ & $\begin{array}{l}\text { Evaluate effectiveness of program } \\
\text { implementation on outcomes } \\
\text { identified in PRECEDE phase of } \\
\text { intervention design and how health } \\
\text { status has changed overall }\end{array}$ & $\begin{array}{l}\text { o Mitigating the health risks (or } \\
\text { surrogate outcomes) as stated in } \\
\text { the REMS Goals } \\
\text { o Rates of expected and } \\
\text { unexpected adverse events } \\
\text { related to REMS implementation } \\
\text { o Unenrollment of patients (due } \\
\text { to safety outcomes being } \\
\text { targeted by the REMS program) }\end{array}$ & $\begin{array}{l}\text { Health } \\
\text { Outcomes and/ } \\
\text { or Surrogates of } \\
\text { Health } \\
\text { Outcomes } \\
\text { Adverse Event } \\
\text { Surveillance }\end{array}$ & $\begin{array}{l}\text { Measures of the safety-related health } \\
\text { outcome of interest or a surrogate of } \\
\text { a health outcome }\end{array}$ \\
\hline
\end{tabular}

Not included: no appropriate category from the Assessment Guidance. Not applicable: not currently assessed in the REMS program to have application

subconstructs the research team developed (Tables 4 and 5).

Of 23 total REMS assessment plans, 18 (78.3\%) contained measures assessing Implementation, with the median number of Implementation assessment measures per assessment plan being 4 (range 0-6). For Process Evaluation, all 23 (100\%) REMS assessment plans included this construct, with the median number of assessment measures per plan being 12 (range 1-26). All 23 (100\%) REMS assessment plans measured Impact Evaluation, with the median number of assessment measures per plan being 10 (range 3-34). Finally, 12 (52\%) assessment plans measured Outcome Evaluation, with a median number of assessment measures per plan being 1 (range 0-6).

For Shared System REMS, the median number of Implementation assessment measures per plan was 1 (range $0-5)$. The median number of Process Evaluation measures per assessment plan was 10 (range 1-26). Notably, the Shared System REMS for emtricitabine tenofovir disoproxil fumarate contained the highest proportion of measures assessing Impact Evaluation, with this construct accounting for $87.5 \%$ of all its assessment measures and the median number of assessment measures 
Table 6 Adaptation of CFIR constructs as applied to REMS assessment measures and Assessment Guidance categories

\begin{tabular}{|c|c|c|c|c|}
\hline CFIR construct & Short description & $\begin{array}{l}\text { Description as Applied } \\
\text { to REMS Assessments }\end{array}$ & $\begin{array}{l}\text { Assessment } \\
\text { Guidance Category }\end{array}$ & $\begin{array}{l}\text { Definitions of Assessment } \\
\text { Guidance Category }\end{array}$ \\
\hline
\end{tabular}

\section{INTERVENTION CHARACTERISTICS} Source

B. Evidence Strength \& Quality

C. Relative Advantage

D. Adaptability The degree to which an intervention can be adapted, tailored, refined, or reinvented to meet local needs.

E. Trialability

G. Design

Quality \&

Packaging

H. Cost

Perception of key stakeholders

Stakeholders' perceptions of the quality and validity of evidence supporting the belief that the intervention will have desired outcomes.

Stakeholders' perception of the advantage of implementing the intervention versus an alternative solution. on a small scale in the organization, and to be able to reverse course (undo implementation) if warranted.

Perceived difficulty of implementation, reflected by duration, scope, radicalness, disruptiveness, centrality, and intricacy and number of steps required to implement.

Perceived excellence in how the and assembled.

Costs of the intervention and
A. Intervention about whether the intervention is externally or internally developed.

The ability to test the intervention intervention is bundled, presented, costs associated with implementing the intervention including investment, supply, and opportunity costs.

\section{OUTER SETTING}

A. Patient Needs The extent to which patient \& Resources needs, as well as barriers and facilitators to meet those needs, are accurately known and addressed by the organization.

B. The degree to which an Cosmopolitanism organization is networked with other external organizations.

C. Peer Pressure Mimetic or competitive pressure to implement an intervention; typically because most or other key peer or competing organizations have already implemented or are in a bid for a competitive edge.

D. External
Perception of key stakeholders' about whether the REMS program is primarily developed externally (FDA/sponsor) or internally.

Stakeholders' perception of the quality and validity of evidence supporting the belief that the program would achieve REMS goals

Stakeholders' perception of the advantage of implementing the REMS versus an alternative solution, or not receiving the access to the product at all.

The degree to which REMS requirements can be adapted, tailored, and refined to meet local needs and ease program implementation.

The degree to which the REMS program can be tested on a local scale or at specified points of care prior to implementation on a national level, or through a modification later in the program.

Perceived difficulty of REMS implementation, reflected by duration, scope, radicalness, disruptiveness, centrality, intricacy, and number of steps required to implement.

Perceived excellence of how the REMS program is bundled, presented, and assembled (i.e. quality of design and execution).

Costs of the REMS program and costs associated with implementing the program including investment, supply, and opportunity costs.

The extent to which the REMS program is patient-focused and that patient needs, as well as barriers and facilitators to meet those needs, are accurately known and addressed by the sponsor.

The extent and quality to which stakeholders are networked within the broader healthcare system to more quickly implement practices.

Competitive pressure for healthcare providers to enroll in a REMS program due to the enrollment of other providers or those in the medical use process.
Not included

Not applicable

Not included

Not applicable

Not included

Not applicable

Not included

Not applicable

Not included Not applicable

Not included

Not applicable

Not included

Not applicable

Not included

Not applicable

Not included

Not applicable

Not included

Not applicable Not included Not applicable 
Table 6 Adaptation of CFIR constructs as applied to REMS assessment measures and Assessment Guidance categories (Continued)

\begin{tabular}{ll}
\hline CFIR construct & Short description \\
\hline Policy \& & external strategies to spread \\
Incentives & interventions, including policy and \\
& regulations (governmental or \\
& other central entity), external \\
& mandates, recommendations and \\
& guidelines, pay-for-performance, \\
& collaboratives, and public or \\
& benchmark reporting.
\end{tabular}

\section{INNER SETTING}

\section{A. Structural The social architecture, age, Characteristics maturity, and size of an organization.}

\section{Description as Applied}

to REMS Assessments

care guidelines, reimbursement systems, and incentives such as pay-for-performance, and benchmark reporting.

\section{Assessment} Guidance Category

Definitions of Assessment Guidance Category

The effects of the point of care's size, degree of vertical integration, number of departments, number

Not included

Not applicable

\begin{tabular}{|c|c|}
\hline $\begin{array}{l}\text { B. Networks \& } \\
\text { Communications }\end{array}$ & $\begin{array}{l}\text { The nature and quality of webs of } \\
\text { social networks and the nature } \\
\text { and quality of formal and informal } \\
\text { communications between } \\
\text { sponsors and their vendors. }\end{array}$ \\
\hline C. Culture & $\begin{array}{l}\text { Norms, values, and basic } \\
\text { assumptions of a given } \\
\text { organization. }\end{array}$ \\
\hline $\begin{array}{l}\text { D. } \\
\text { Implementation } \\
\text { Climate }\end{array}$ & $\begin{array}{l}\text { The absorptive capacity for } \\
\text { change, shared receptivity of } \\
\text { involved individuals to an } \\
\text { intervention, and the extent to } \\
\text { which use of that intervention will } \\
\text { be rewarded, supported, and } \\
\text { expected within their organization }\end{array}$ \\
\hline $\begin{array}{l}\text { E. Readiness for } \\
\text { Implementation }\end{array}$ & $\begin{array}{l}\text { Tangible and immediate indicators } \\
\text { of organizational commitment to } \\
\text { its decision to implement an } \\
\text { intervention. }\end{array}$ \\
\hline
\end{tabular}

\section{CHARACTERISTICS OF INDIVIDUALS}

A. Knowledge \& Individuals' attitudes toward and Beliefs about the value placed on the intervention Intervention as well as familiarity with facts, truths, and principles related to the intervention.

\section{B. Self-efficacy Individual belief in their own capabilities to execute courses of action to achieve implementation goals. \\ C. Individual Characterization of the phase an Stage of Change individual is in, as he or she progresses toward skilled, enthusiastic, and sustained use of the intervention.} of units/departments, and degree of specialization on the implementation of individual REMS programs.

The strength of formal and informal communications, networking, and relationships between sponsors, vendors, and points of care and their effects on the adoption of the REMS program and understanding of its goals.

The norms, values, and basic assumptions about risk management and the REMS program at the point of care and the extent of how relatively stable, subconscious, and socially constructed these are.

The absorptive capacity for change, shared receptivity of involved individuals to the program, and the extent to which use of the REMS will be rewarded, supported, and expected through policies, procedures, and systems within the points of care.

Tangible and immediate indicators Not included of stakeholders' readiness for adoption of the REMS in terms of setting, culture, leadership, and evaluation.

Participants' attitudes toward and value placed on the REMS as well as familiarity with facts, truth, and principles related to the program, including sufficient knowledge of the necessity for and skill of executing the REMS program.

Participants' belief in their own capabilities to execute courses of action to achieve REMS goals.

Characterization of the phase a participant is in and additional strategies necessary for the skilled and enthusiastic maintenance of behavior.

Not included

Not included

Not included

Not applicable

Not applicable

Not applicable

Not applicable

Knowledge

Not included

Safe Use Behaviors Sare Use Behaviors
Measures of the extent of stakeholders' knowledge about the REMS-related risk or knowledge of any safe use conditions that are needed in order to mitigate the risk

Not applicable

Measures of the extent to which safe use conditions are being adopted or followed 
Table 6 Adaptation of CFIR constructs as applied to REMS assessment measures and Assessment Guidance categories (Continued)

\begin{tabular}{|c|c|c|c|c|}
\hline CFIR construct & Short description & $\begin{array}{l}\text { Description as Applied } \\
\text { to REMS Assessments }\end{array}$ & $\begin{array}{l}\text { Assessment } \\
\text { Guidance Category }\end{array}$ & $\begin{array}{l}\text { Definitions of Assessment } \\
\text { Guidance Category }\end{array}$ \\
\hline $\begin{array}{l}\text { D. Individual } \\
\text { Identification } \\
\text { with } \\
\text { Organization }\end{array}$ & $\begin{array}{l}\text { A broad construct related to how } \\
\text { individuals perceive the } \\
\text { organization, and their relationship } \\
\text { and degree of commitment with } \\
\text { that organization. }\end{array}$ & $\begin{array}{l}\text { A broad construct related to how } \\
\text { participants perceive the REMS } \\
\text { and their willingness to fully } \\
\text { engage due to their degree of } \\
\text { commitment with the sponsor. }\end{array}$ & Not included & Not applicable \\
\hline $\begin{array}{l}\text { E. Other } \\
\text { Personal } \\
\text { Attributes }\end{array}$ & $\begin{array}{l}\text { A broad construct to include other } \\
\text { personal traits such as tolerance of } \\
\text { ambiguity, intellectual ability, } \\
\text { motivation, values, competence, } \\
\text { capacity, and learning style. }\end{array}$ & $\begin{array}{l}\text { A broad construct to include other } \\
\text { personal traits such as participants' } \\
\text { locus of control and other } \\
\text { psychological concepts related to } \\
\text { REMS implementation. }\end{array}$ & Not included & Not applicable \\
\hline \multicolumn{5}{|l|}{ V. PROCESS } \\
\hline A. Planning & $\begin{array}{l}\text { The degree to which a scheme or } \\
\text { method of behavior and tasks for } \\
\text { implementing an intervention are } \\
\text { developed in advance, and the } \\
\text { quality of those schemes or } \\
\text { methods. }\end{array}$ & $\begin{array}{l}\text { The degree to which a scheme or } \\
\text { method of behavior and tasks for } \\
\text { implementing the REMS are } \\
\text { developed in advance, and the } \\
\text { quality of the evidence supporting } \\
\text { those steps to promote effective } \\
\text { implementation. }\end{array}$ & Not included & Not applicable \\
\hline B. Engaging & $\begin{array}{l}\text { Attracting and involving } \\
\text { appropriate individuals in the } \\
\text { implementation and use of the } \\
\text { intervention through a combined } \\
\text { strategy of social marketing, } \\
\text { education, role modeling, training, } \\
\text { and other similar activities. }\end{array}$ & $\begin{array}{l}\text { Carefully and thoughtfully } \\
\text { attracting involving appropriate } \\
\text { representatives from each } \\
\text { stakeholder group in the } \\
\text { implementation of the REMS } \\
\text { program through a combined } \\
\text { strategy of social marketing, } \\
\text { education, role modeling, training, } \\
\text { and other similar activities to meet } \\
\text { participants' needs. }\end{array}$ & $\begin{array}{l}\text { Program Outreach } \\
\text { and Communication }\end{array}$ & $\begin{array}{l}\text { Measures of the extent to which } \\
\text { the REMS materials reached the } \\
\text { intended stakeholders }\end{array}$ \\
\hline C. Executing & $\begin{array}{l}\text { Carrying out or accomplishing the } \\
\text { implementation according to plan. }\end{array}$ & $\begin{array}{l}\text { Carrying out or accomplishing the } \\
\text { REMS program according to plan } \\
\text { (descriptive). }\end{array}$ & $\begin{array}{l}\text { Program } \\
\text { Implementation and } \\
\text { Operations }\end{array}$ & $\begin{array}{l}\text { Measures of the extent to which } \\
\text { the intended stakeholders are } \\
\text { participating in the program, how } \\
\text { effectively the REMS program is } \\
\text { being implemented and any } \\
\text { unintended consequences such as } \\
\text { patient access or burden to the } \\
\text { healthcare system }\end{array}$ \\
\hline $\begin{array}{l}\text { D. Reflecting \& } \\
\text { Evaluating }\end{array}$ & $\begin{array}{l}\text { Quantitative and qualitative } \\
\text { feedback about the progress and } \\
\text { quality of implementation } \\
\text { accompanied with regular } \\
\text { personal and team debriefing } \\
\text { about progress and experience. }\end{array}$ & $\begin{array}{l}\text { Quantitative and qualitative } \\
\text { feedback (evaluative) about the } \\
\text { progress and quality REMS } \\
\text { implementation accompanied } \\
\text { with regular personal and team } \\
\text { debriefing about progress and } \\
\text { experience. }\end{array}$ & $\begin{array}{l}\text { Program } \\
\text { Implementation and } \\
\text { Operations }\end{array}$ & $\begin{array}{l}\text { Measures of the extent to which } \\
\text { the intended stakeholders are } \\
\text { participating in the program, how } \\
\text { effectively the REMS program is } \\
\text { being implemented and any } \\
\text { unintended consequences such as } \\
\text { patient access or burden to the } \\
\text { healthcare system }\end{array}$ \\
\hline
\end{tabular}

Not included: no appropriate category from the Assessment Guidance. Not applicable: not currently assessed in the REMS program to have application

per plan being 9 (4-34). Finally, only 2 Shared System REMS contained assessment measures of Outcome Evaluation, with the median number of Outcome Evaluation measures per plan mirroring that of the larger group at 0 (range $0-6)$.

Of the three frameworks, assessment items mapped to PRECEDE-PROCEED were most evenly distributed across the constructs. (Fig. 1). PROCEED constructs mapped most directly with those of the assessment guidance, with Implementation to Outreach and Communications, Process Evaluation to Implementation and Operations, Impact Evaluation to Safe Use Behaviors and Knowledge, and Outcome Evaluation to Health Outcomes.

\section{Insights from the application of CFIR to REMS}

Developed out of 20 sources including the Diffusion of Innovations Theory, CFIR has been used for quality improvement [21]. Designed to provide a menu of constructs to be adaptable to a variety of applications, only the Characteristics of Individuals and Process constructs were most appropriate to REMS. Specifically, only the Knowledge and Beliefs about the Intervention and Individual Stage of Change under the Characteristics of 


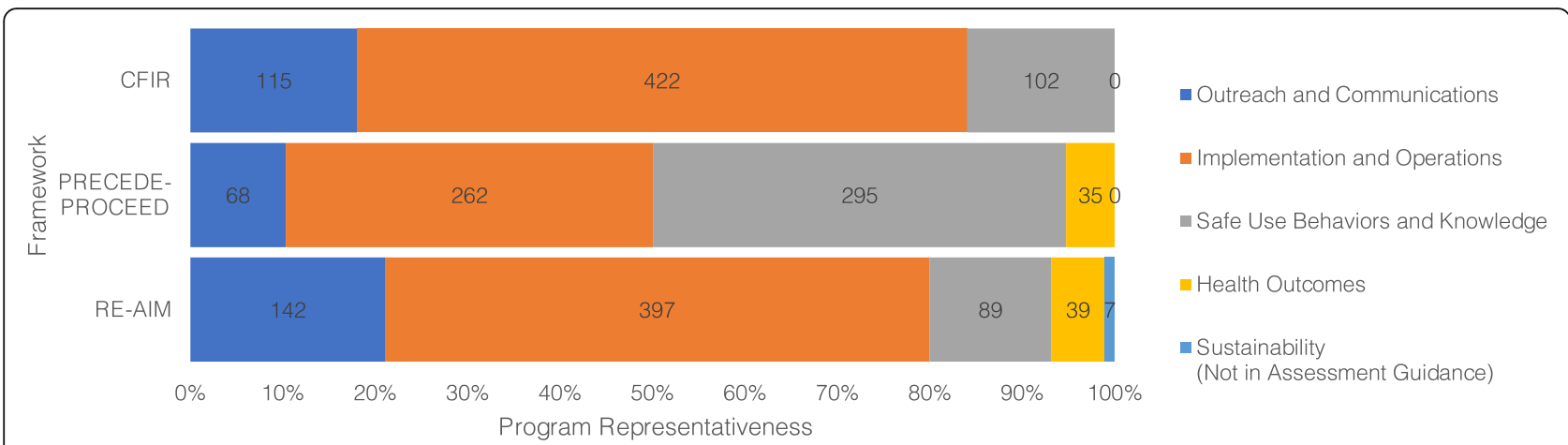

Fig. 1 Number of REMS assessment measures $(n=674)$ across programs $(N=23)$ mapped to the Assessment Guidance by framework. CFIR, Consolidated Framework for Implementation Research; PRECEDE-PROCEED, Predisposing, Reinforcing Enabling, Construct in, Educational, Diagnosis and Evaluation - Policy, Regulatory, Organizational, Construct in, Educational and Environmental, Development; RE-AIM, Reach, Effectiveness, Adoption, Implementation, Maintenance

Individuals construct, and the Engaging, Executing, and Reflecting and Evaluating under the Process constructs were applicable to REMS.

It is critical to note that CFIR is evidence-based, assuming the intervention is effective, and therefore does not measure outcomes. Given this, 5\% of REMS assessment measures (34 of 674) did not map to the framework because they were outcome measures. Due to CFIR's multilevel nature, it was important to define the "Inner Setting" to refer to individual sites of specific REMS programs, and "Outer Setting" to refer to the broader healthcare system inclusive of patients. A criticism of CFIR is the fact that its "combined breadth and depth is not always feasible for implementation," [27]; however, its design for clinical quality improvement meant that it was easily customizable to a variety of REMS situations across diverse settings. In this context, "Characteristics of Individuals" was determined to represent any stakeholder (e.g. patient or provider) within that setting.

Of 23 total REMS assessment plans, 1 (4.4\%) contained measures assessing Intervention Characteristics (Table 6), with the median number of Intervention Characteristics assessment measures per assessment plan being 2 (range $0-7$ ). None of the REMS assessment measures included constructs that relate to Outer Setting and Inner Setting. Characteristics of Individuals were measured in 21 REMS assessment plans (91\%), with the median number of assessment measures per plan being 18 (range 0-8) Finally, all 23 (100\%) assessment plans measured Process, with a median number of assessment measures per plan being 20 (range 1-57).

Among Shared System REMS, the median number of Intervention Characteristics assessment measures per plan was 0 (range $0-0$ ). Similarly, none of the REMS assessment plans contained measures of the Outer Setting or Inner Setting. Notably, the Shared System REMS for emtricitabine tenofovir disoproxil fumarate contained the highest proportion of measures assessing Characteristics of Individuals, with this construct accounting for 87.5\% of all its assessment measures. Across all Shared System REMS, Characteristics of Individuals was assessed at a median of 7 (range 1-8) measures. Finally, the median number of Process assessment measures was 16 (range 1-57) amongst Shared System plans.

Applied to the Assessment Guidance, Knowledge and Beliefs about the Intervention and Individual Stage of Change mapped to Knowledge and Safe Use Behaviors (Fig. 1). The Process construct of Engaging mapped to Outreach and Communications, while both Executing and Reflecting and Evaluating mapped to Program Implementation and Operations. Regarding the Program Implementation and Operations constructs, Executing is akin to the descriptive analysis, or descriptions of the aspects of the REMS implementation process, while Reflecting and Evaluating refer to the evaluative and causal analysis, or the corrective and preventive actions in REMS and the determination of the reasoning behind certain implementation processes.

\section{Discussion}

To our knowledge, this is the first systematic comparative content analysis of several leading implementation science frameworks and their relative applicability and feasibility for nationally-regulated pharmaceutical risk minimization program assessment. Our evaluation found three established implementation science frameworks to be pragmatic in utility, making application to REMS programs relatively intuitive.

For example, RE-AIM considerations for evaluating health promotion programs and policies fit well with the need to evaluate REMS program recipients (like prescribers) who are agents for delivering the program to others (like patients). Application of the PROCEED 
constructs was also straightforward, especially with Implementation and Outcomes Evaluation, which directly matched REMS assessment categories. Overall, all three frameworks had very strong congruence with REMS assessment items, with at least $95 \%$ of items mapping to a single construct for each of the frameworks.

\section{Comparison of RE-AIM, PRECEDE-PROCEED, and CFIR for evaluating REMS programs}

Our application of implementation science to the Assessment Guidance found that most REMS assessment measures for programs approved between 2014 and 2018 fell under Implementation and Operations, which is reasonable given FDA's authority to require REMS and its experiences reviewing REMS implementation by the sponsors. Additionally, process data are understood to be more sensitive measures of the quality of a program than outcome data, as a poor outcome does not always occur as a result of an error in the provision of care [28]. Our analysis also found less emphasis on REMS assessment measures related to Health Outcomes. This may be because the FDA relies on good pharmacovigilance practices and pharmacoepidemiologic assessment, versus the REMS assessment itself, to collect information on safety events [29]. Interestingly, a Shared System REMS was more likely to include measures related to Health Outcomes or Safe Use Behaviors and Knowledge. This may be explained by the fact that Shared System REMS reflect sustaining programs, where processes had been implemented for some time, allowing for more opportunity to evaluate sustained effectiveness on population health outcomes.

Table 7 compares and contrasts the key strengths and limitations of RE-AIM, PRECEDE-PROCEED, and CFIR as applied to REMS programs. Based on our assessment, no single unifying framework is likely applicable for all FDA-mandated programs. Rather, each framework merits relative scientific strengths and selection should be tailored based on the need of the specific program. The evaluation also identified opportunities to further strengthen REMS program evaluation, including measures to assess institutional implementation climate (from CFIR); measures to assess the representativeness of program participation and sustainability (from REAIM); and measures to assess health care provider and patient values and preferences (from PRECEDEPROCEED). The following describes the relative strengths and limitations in greater detail:

\section{RE-AIM}

As a program evaluation framework, RE-AIM aims to "improve sustainable adoption and implementation." [26] One strength was how simple-to-use RE-AIM was and how easily adaptable it was to a spectrum of REMS assessment measures. Another was that it considers the representativeness of patients and providers [18]. This inclusion of participants' characteristics allows for the assessment of heterogeneity of impact, which subsequently permits evaluations of patient burden and access. Health outcomes can be better measured as suggested by RE-AIM through predetermination of objectives and their impact on the changes in knowledge and safe use behaviors. REMS assessment could be strengthened by more deliberate inclusion of the REAIM Maintenance construct. For example, assessment measures could evaluate the evidence for integration of REMS processes and procedures into institutional policies, attrition of healthcare providers over time, or the extent to which health outcomes are sustained as a result of patient educational training [30], generating evidence for the decision of potentially releasing a REMS. If FDA started with RE-AIM to develop their REMS assessments, there could be a more even distribution of items, with more on sustainability of health care setting

Table 7 Comparison of implementation science frameworks as applied to REMS program assessment

\begin{tabular}{|c|c|c|}
\hline Framework & Strengths & Limitations \\
\hline RE-AIM & $\begin{array}{l}\text { - Flexible and intuitively generalizable to REMS program } \\
\text { evaluation; has been applied across a wide range of clinical, public } \\
\text { health, and educational settings. } \\
\text { - Includes assessment of program sustainability, which enables } \\
\text { constructs assessing burden on the healthcare delivery system and } \\
\text { barriers to patient access }\end{array}$ & $\begin{array}{l}\text { - Requires careful delineation of adoption (i.e., among REMS health } \\
\text { care implementers) vs. reach (i.e., among patients receiving the } \\
\text { drug and thereby the benefits of the risk mitigation measures) } \\
\text { - Traditionally, an evaluation tool, although it has been used to } \\
\text { inform program design }\end{array}$ \\
\hline $\begin{array}{l}\text { PRECEDE- } \\
\text { PROCEED }\end{array}$ & $\begin{array}{l}\text { - Explicitly links program design assumptions with program } \\
\text { evaluation metrics } \\
\text { - Supports continuous process improvement evaluation, which } \\
\text { enables REMS modification and revision over time }\end{array}$ & $\begin{array}{l}\text { - Phases narrowly defined, requiring at times broader application } \\
\text { - Traditionally, applied to population-health programs; may be less } \\
\text { applicable for some clinical settings (e.g., provider activities in a } \\
\text { hospital) }\end{array}$ \\
\hline CFIR & $\begin{array}{l}\text { - Integrates key constructs from multiple implementation science } \\
\text { frameworks } \\
\text { - Includes health system organizational measures, such as, } \\
\text { administrative and leadership endorsement and organizational } \\
\text { readiness to change, which enables greater evaluation of program } \\
\text { implementation and operations }\end{array}$ & $\begin{array}{l}\text { - Less intuitive to apply to REMS program evaluation, with } \\
\text { categories often overlapping or including repetitive constructs } \\
\text { - Focused on evaluating program implementation, lacking } \\
\text { measures to assess health outcomes and impact } \\
\text { - Traditionally, applied to clinical quality improvement programs; } \\
\text { may be less applicable for some non-clinical settings (e.g., patient } \\
\text { activities at home) }\end{array}$ \\
\hline
\end{tabular}


processes and individual behaviors and less on fidelity to every single process measure.

\section{PRECEDE-PROCEED}

Although intuitive to apply, not every construct mapped perfectly to a REMS measure. Some measures mapped to multiple constructs, while others did not map to a single construct. The framework does not specifically analyze outreach to providers, although it does focus on community and/or patient needs in general. A strength of the framework is that it thoroughly considers assessment of situational factors that may affect the outcome of an intervention. PRECEDE-PROCEED suggests assessment plans could make note of questions made to the REMS call center that could shed light on the differences in the tolerance for burden between individuals and subgroups. However, it is important to note that the framework does not assess resources and therefore may not be a good model for evaluating program burden. One way to strengthen the application of PRECEDEPROCEED for REMS is to create subconstructs within PROCEED constructs as we did and assign each by participant; for example, subconstruct 7B of the Process Evaluation construct would apply only to healthcare provider measures, while subconstruct $7 \mathrm{C}$ also of the Process Evaluation construct would apply to patients.

\section{CFIR}

Our application of CFIR to REMS assessment found the framework to "open[] the 'black box' of ... implementation" and be fruitful in evaluating implementation progress in a clinical setting, as the authors intended [31]. We were able to select constructs most relevant for REMS assessments, namely those falling under Process and Characteristics of Individuals. Some of these measures involved Reflecting and Evaluating on program implementation to improve processes. CFIR can also be used as a guide to formative evaluations for FDA to improve REMS assessments by considering constructs under Intervention Characteristics, the Outer Setting, and the Inner Setting. Through its 39 different subconstructs, CFIR can also inform the design and conduct of REMS. For example, on the construct of Intervention Characteristics, Adaptability can be measured in the earlier REMS assessment plans to evaluate the degree to which REMS requirements must be tailored and refined to meet local needs and sponsor capacities. In the Outer Setting, Patient Needs and Resources can be assessed to the extent that the REMS program is patient-focused and addresses patient barriers. Measures of participants' knowledge about the REMS-related risk or of any safe use conditions that are needed to mitigate the risk can be aided by assessment of the participant's values and attitudes towards that knowledge or safe use behavior.
Participants' Readiness for Implementation including physical resources, leadership engagement, and culture can also be assessed under the Inner Setting. Validating design assumptions would then allow for more thoughtful modifications and ultimately improve program performance. If FDA develops REMS assessment measures starting from CFIR, there would be considerations about the design aspects of the REMS characteristics, thoughts about how the REMS would fit into the broader healthcare setting, and participants' receptiveness about the REMS.

\section{Implications for regulated risk management plans}

The use of frameworks offers several advantages to advance the science of pharmaceutical risk minimization program evaluation. First, grounding assessment plans through frameworks encourages consistency, standardization, and completeness in evaluating REMS to facilitate cross program comparisons and foster generalizable knowledge. Second, frameworks are valuable for building the evidence base for synthesizing implementation strategies to improve outcomes. They can be used to drive data towards more meaningful information and increase the likelihood that REMS design, implementation, and outcomes are effective. Currently, setting, context and implementation strategy selection are under-reported in published evaluations making it difficult to compare effectiveness [32]. Conceptual models have been proposed for developing efficient strategies for the measurement of the effectiveness of European Medicines Agency RMMs [33]. Like REMS, RMMs can also benefit from the application of implementation science in the aspects of the delivery context, attributes of the proposed intervention, and characteristics of the intended adopters [15].

Although the present evaluation focused on using implementation science frameworks for REMS assessment, these frameworks can also be used to inform REMS design. For example, the goal of the Addyi REMS program is to mitigate the increased risk of syncope and hypotension associated with drinking while taking the medication. Because patients' current and past drinking behavior must be assessed before Addyi is prescribed, a framework focused on changing health behavior might be most suitable [34]. PRECEDE-PROCEED considers the spectrum of behavior change from the predisposing, enabling, and reinforcing factors to the impact of the program on these factors and could therefore inform a REMS program like Addyi that is designed to change behavior. REMS programs with health education as its main intent, such as the Opioid Analgesic REMS, could benefit from using RE-AIM as this framework not only poses questions related to assessing individuals reached and the immediate and long-term effectiveness of the 
knowledge transfer but also how the setting and operations could facilitate or impede the change in knowledge [35]. Finally, as CFIR focuses on implementing evidencebased interventions with demonstrated effectiveness, it is a suitable framework for a Shared System REMS such as that of bosentan where the goal is to sustain implementation effectiveness as new drugs or generics enter the Shared System REMS [36].

Lastly, under FDA's PDUFA V commitments to modernize post-marketing drug safety evaluation, it has committed to efforts on implementing a structured benefit-risk assessment process [37]. The benefit-risk assessment framework has identified "Risk and Risk Management" as one explicit dimension, with an area of interest concerning how information on evidence and uncertainties can be communicated to the public. Implementation science frameworks can be used to ensure that risk management uncertainties are systematically evaluated and categorized based on factors known to affect real-world implementation of health programs. In turn, this level of rigor in a policy context facilitates the selection of interventions with clinical benefit for healthcare organizational settings to ultimately improve patient health.

\section{Conclusions}

As FDA considers feedback from stakeholders and public comments in its finalization of the Assessment Guidance, this research can serve as one source of input. This research demonstrates the feasibility of implementation science frameworks to be applied to REMS assessment plans. Frameworks such as RE-AIM, PRECEDEPROCEED, and CFIR provide a logical, structured approach for determining what should be measured, when they should be measured, and the process and impact indicators for facilitating these measurements. Application of implementation science to REMS assessment measures reveals a need to consider the design and sustainability of REMS programs in the assessment plans. Future REMS assessment plans can consider an element from each of the three frameworks adapted, including patient values and preferences, representativeness, and the implementation climate. Using this information, sponsors can evaluate matters of stakeholder interest, such as patient burden and access through assessment of heterogeneity. Burdens on patients and the healthcare system can be further reduced by determining core explanatory measures for every step of the evaluation continuum to prevent unnecessary interventions when one core primary measure would be sufficient for determining whether the REMS goal could be met.

\section{Abbreviations}

ANDA: Abbreviated new drug application; BLA: Biologic license application; CFIR: Consolidated framework for implementation research;
CP: Communication plan; ETASU: Elements to assure safe use; FDA: Food and drug administration; MG: Medication guide; NDA: New drug application; PDUFA: Prescription drug user fee act; PRECEDE-PROCEED: Predisposing, reinforcing, and enabling constructs in educational diagnosis and evaluation - policy, regulatory, organizational, construct in, educational and environmental, development; RE-AIM: Reach effectiveness adoption implementation maintenance; REMS: Risk evaluation and mitigation strategies; RMM: Risk minimization measures

\section{Supplementary Information}

The online version contains supplementary material available at https://doi. org/10.1186/s12913-021-06808-3.

Additional file 1. Examples of search strings used to identify frameworks for assessing REMS programs.

Additional file 2. Assessment Guidance categories mapped to framework constructs.

Additional file 3. Flow diagram of 2014-2018 active REMS with ETASU program selection for content analysis of assessment plans.

\section{Acknowledgements}

The authors would like to thank FDA colleagues Claudia Manzo, PharmD and Cynthia LaCivita, PharmD for reviewing and editing this work. Contents are the authors' sole responsibility and do not necessarily represent official FDA views or policies.

\section{Authors' contributions}

$\mathrm{LH}$ analyzed and interpreted data resulting from the mapping of REMS assessment plans to the frameworks and was a major contributor in writing the manuscript. GT made substantial contributions to the conception and design of the work and provided critical revision of the manuscript for important intellectual content. EM made substantial contributions to the conception and design of the work and contributed to the analysis and interpretation of data. All authors contributed to, read, and approved the final manuscript.

\section{Funding}

$\mathrm{LH}$ received financial support by an appointment to the Research Participation Program at the U.S. Food and Drug Administration (FDA) administered by the Oak Ridge Institute for Science and Education (ORISE) through an interagency agreement between the U.S. Department of Energy (DOE) and FDA. GT is employed by the U.S. Food and Drug Administration and has no conflicts of interest to declare. EM received financial support by an Intergovernmental Personnel Act appointment to the U.S. Food and Drug Administration, Office of Surveillance and Epidemiology, administered through the University of Colorado.

Availability of data and materials

The data that support the findings of this study are available from the corresponding author upon reasonable request.

\section{Declarations}

Ethics approval and consent to participate

Not applicable.

Consent for publication

Not applicable.

\section{Competing interests}

The authors declare they have no competing interests.

\section{Author details}

${ }^{1}$ Food and Drug Administration, Silver Spring, MD, USA. ${ }^{2}$ Oak Ridge Institute for Science and Education (ORISE) Program, Oak Ridge, TN, USA. ${ }^{3}$ Parkinson School of Health Sciences and Public Health, Loyola University Chicago, Chicago, IL, USA. ${ }^{4}$ Colorado School of Public Health, University of Colorado Anschutz Medical Campus, Aurora, CO, USA. 
Received: 11 January 2021 Accepted: 22 July 2021

Published online: 06 August 2021

\section{References}

1. Food and Drug Administration Amendments Act of 2007, HR, 110th Congress Sess. (2007).

2. FDA. FDA's Application of Statutory Factors in Determining When a REMS Is Necessary 2019 [cited FDA. Drug Safety] Available from: https://www.fda. gov/regulatory-information/search-fda-guidance-documents/fdas-applica tion-statutory-factors-determining-when-rems-necessary.

3. FDA. NDA and BLA Calendar Year Approvals. Drugs 2019.

4. FDA. Biological Approvals by Year. Vaccines, Blood \& Biologics. 2019

5. FDA. Risk Evaluation and Mitigation Strategies | REMS 2019 Available from: https://www.fda.gov/drugs/drug-safety-and-availability/risk-evaluation-andmitigation-strategies-rems.

6. FDA. Approved Risk Evaluation and Mitigation Strategies (REMS). Drug Databases.

7. CRS. The SUPPORT for Patients and Communities Act (P.L. 115-271): Food and Drug Administration and Controlled Substance Provisions. 2018 November 15. Contract No.: R45405.

8. FDA. REMS Assessment: Planning and Reporting 2019 [cited Food and Drug Administration] Available from: https://www.fda.gov/regulatory-information/ search-fda-guidance-documents/rems-assessment-planning-and-reporting.

9. Risk Evaluation and Mitigation Strategies, (2007).

10. FDA. Risk Evaluation and Mitigation Strategies Assessment: Planning and Reporting; Draft Guidance for Industry; Availability 2019 [1153-5]. Available from: https://www.govinfo.gov/content/pkg/FR-2019-02-01/pdf/2019-00676. pdf.

11. Levinson DR. FDA Lacks Comprehensive Data to Determine Whether Risk Evaluation and Mitigation Strategies Improve Drug Safety: Services DoHaH; 2013. Contract No.: OEl-04-11-00510

12. CDER, editor Standardizing and Evaluating Risk Evaluation and Mitigation Strategies (REMS). FDA Public Meeting; 2013.

13. BMC. Implementation Science: Aims and Scope. Available from: https:// implementationscience.biomedcentral.com/about.

14. Toyserkani GA, Huynh L, Morrato EH. Characteristics of risk evaluation and mitigation strategies (REMS) assessment plans: A review of REMS with ETASU (2014-2018) using RE-AIM. 35th International Conference on Pharmacoepidemiology \& Therapeutic Risk Management; August 20, 2019; Pennsylvania Convention Center, Philadelphia, PA, USA, August 24-28, 2019. 2019. p. 466.

15. Smith MY, Morrato E. Advancing the field of pharmaceutical risk minimization through application of implementation science best practices. Drug Saf. 2014;37(8):569-80. https://doi.org/10.1007/s40264-014-0197-0.

16. Smith MY, Russell A, Bahri P, Mol PGM, Frise S, Freeman E, et al. The RIMES statement: a checklist to assess the quality of studies evaluating risk minimization programs for medicinal products. Drug Saf. 2018;41(4):389401. https://doi.org/10.1007/s40264-017-0619-x.

17. Module, X.V.I. Addendum II (2021). Guideline on good pharmacovigilance practices (GVP).

18. Toyserkani GA, Huynh L, Morrato EH. Adaptation for Regulatory Application: A Content Analysis of FDA Risk Evaluation and Mitigation Strategies Assessment Plans (2014-2018) Using RE-AIM. Front Public Health. 2020;8(43).

19. Curran GM, Bauer M, Mittman B, Pyne JM, Stetler C. Effectivenessimplementation hybrid designs. Med Care. 2012;50(3):217-26. https://doi. org/10.1097/MLR.0b013e3182408812.

20. Workgroup R-A. What is RE-AIM? The Basics. Available from: http://www.re-a im.org/about/frequently-asked-questions/.

21. Research CRT-CfCM. The Consolidated Framework for Implementation Research 2019 [Available from: https://cfirguide.org/].

22. RHIhub. PRECEDE-PROCEED [Available from: https://www.ruralhealthinfo. org/toolkits/health-promotion/2/program-models/precede-proceed].

23. Chan-Liston M, Bourke J, Sheehan P, Niemcryk S, Peng M, Bwire R, et al. 17th ISoP Annual Meeting "Pharmacovigilance in the 21st Century" Liverpool, UK 15-18 October, 2017 Drug Safety2017. p. 937-1045.

24. FDA. REMS Assessment: Planning and Reporting. In: DHHS, editor. 2019.

25. FDA. Development of a Shared System REMS 2018 [Available from: https:// www.fda.gov/files/drugs/published/Development-of-a-Shared-System-REMSGuidance-for-Industry.pdf.

26. Workgroup R. Frequently Asked Questions 2019 [Available from: http:// www.re-aim.org/about/frequently-asked-questions/.
27. Safaeinili N, Brown-Johnson C, Shaw JG, Mahoney M, Winget M. CFIR simplified: pragmatic application of and adaptations to the consolidated framework for implementation research (CFIR) for evaluation of a patientcentered care transformation within a learning health system. Learning Health Systems. 2020;4(1):e10201. https://doi.org/10.1002//rh2.10201.

28. Brook RH, McGlynn EA, Cleary PD. Measuring quality of care. Mass Medical Soc. 1996.

29. Tobenkin A. An Introduction to Drug Safety Surveillance and the FDA Adverse Event Reporting System. 2018.

30. Partners K. The Kirkpatrick Model 2020.

31. Damschroder LJ, Aron DC, Keith RE, Kirsh SR, Alexander JA, Lowery JC. Fostering implementation of health services research findings into practice: a consolidated framework for advancing implementation science. Implement Sci. 2009;4(1):50. https://doi.org/10.1186/1748-5908-4-50.

32. Russell AM, Morrato EH, Lovett RM, Smith MY. Quality of reporting on the evaluation of risk minimization programs: a systematic review. Drug Saf. 2020:1-20.

33. Mazzaglia G, Straus SM, Arlett P, da Silva D, Janssen H, Raine J, et al. Study design and evaluation of risk minimization measures: a review of studies submitted to the European medicines agency for cardiovascular, endocrinology, and metabolic drugs. Drug Saf. 2018;41(2):191-202. https:// doi.org/10.1007/s40264-017-0604-4

34. Addyi (flibanserin) [package insert]. Raleigh NSP.

35. FDA. Opioid Analgesic REMS 2019. Available from: https://www.accessdata. fda.gov/scripts/cder/rems/index.cfm?event=RemsDetails.page\&REMS=17.

36. Xyrem (sodium oxybate) - First-Time Generic OptumRx News. 2017.

37. FDA. Benefit-Risk Assessment in Drug Regulatory Decision-Making 2018 [Available from: https://www.fda.gov/files/about\%20fda/published/BenefitRisk-Assessment-in-Drug-Regulatory-Decision-Making.pdf].

\section{Publisher's Note}

Springer Nature remains neutral with regard to jurisdictional claims in published maps and institutional affiliations.

\section{Ready to submit your research? Choose BMC and benefit from:}

- fast, convenient online submission

- thorough peer review by experienced researchers in your field

- rapid publication on acceptance

- support for research data, including large and complex data types

- gold Open Access which fosters wider collaboration and increased citations

- maximum visibility for your research: over $100 \mathrm{M}$ website views per year

At BMC, research is always in progress.

Learn more biomedcentral.com/submissions 